\title{
Perceptions of Science Teachers on Implementation of Seven Principles for Good Practice in Education by Chickering and Gamson in Courses
}

\author{
Mustafa Uğraş ${ }^{1}$, Erol Asiltürk ${ }^{2}$ \\ ${ }^{1}$ Firat University, Education Faculty, Department of Basic Education, 23119, Elazig, Turkey \\ ${ }^{2}$ Firat University, Education Faculty, Department of Science Education, 23119, Elazig, Turkey \\ Correspondence: Mustafa Uğraş, Firat University, Education Faculty, Department of Basic Education, 23119, Elazig, \\ Turkey.
}

Received: January 24, 2018

doi:10.11114/jets.v6i3.3056
Accepted: February 12, $2018 \quad$ Online Published: February 24, 2018

URL: https://doi.org/10.11114/jets.v6i3.3056

\begin{abstract}
The present study aimed to determine the perceptions of science teachers on the implementation of the seven principles for good practice in education by Chickering and Gamson in their courses. Seven principles for good science education were used as a data collection tool in the survey. "The seven principles for good practice in science education scale" for teachers was used as the data collection instrument in the study. "The seven principles for good practice in science education scale" is the adapted form of the "Seven Principles for Good Practice in Education: Faculty Inventory" developed by Chickering and Gamson into Turkish language and junior high school science courses. The scale was applied to 285 science teachers employed in Elazığ province in Turkey and interviews were conducted with 45 teachers. Analysis of the study data demonstrated that the surveyed teachers implemented each of these seven principles at different levels. Conducted interviews revealed the examples of different strategies adopted by the teachers in implementing the abovementioned seven principles.
\end{abstract}

Keywords: good practices in education, seven principles for good education, science education, perception

\section{Introduction}

Rapid economic, social, scientific and technological advances introduce changes to the ways we experience our lives. Globalization, international economic competition, rapid scientific and technological developments will continue to affect our lives in the future. Based on these developments, in contemporary times when the need to train deliberative, critical, equipped and inquisitive individuals who are aware of the requirements of the age, predisposed to scientific knowledge increases continuously, especially science instruction is important in addition to other factors (MEB, 2005).

Training the human resources that would be active in sciences is only possible with instruction of scientific subjects in primary, secondary and higher education. A good science education provided at school can improve the innate curiosity of the children towards their environment and giide them to scientific fields after secondary school (Çilenti, 1985). The fact Turkey ranked poorly in recent international tests demonstrated the problems associated with the science education in schools.

In their long-lasting research, Chickering and Gamson interviewed several experts to determine the worldwide standards of good education and eventually published the study titled "Seven Principles for Good Practice in Undergraduate Education" in American Association for Higher Education (AAHE) Bulletin on March 1987 (Chickering and Gamson, 1987, Gamson, 1991). These seven principles proposed by Chickering and Gamson are as follows: "(1) encourages contacts between students and faculty; (2) develops reciprocity and cooperation among students; (3) uses active learning techniques; (4) gives prompt feedback; (5) emphasizes time on task; (6) communicates high expectations; and (7) respects diverse talents and ways of learning."

In 1989, Chickering and Gamson developed an instrument called "Seven Principles for Good Practice in Undergraduate Education: Faculty Inventory" to scrutinize and examine the applicability of the principles (Chickering, Gamson and Barsi, 1989). Between 1987 and 1991, more than 500,000 copies of the abovementioned inventory were requested by colleges, universities and institutes, and since then hundreds of thousands of copies were distributed to colleges, universities and institutes in the United States and in different parts of the world (Philip, 2011). Pascarella et al. stated 
that the demand and interest by the scientific world for the seven principled developed by Chickering and Gamson were the evidence for the validity and fitness of the seven principles (Pascarella, Wolniack, Cruce and Blaich, 2004). Why is this problem important?

The present study aimed to determine the perceptions of science teachers on the implementation of the seven principles for good practice in education developed by Chickering and Gamson. The present study was conducted to resolve to the following main problem: what are the perceptions of science teachers on the implementation of the seven principles for good practice in education developed by Chickering and Gamson?

\section{Method}

The present study aimed to determine the perceptions of science teachers on the implementation of the seven principles developed by Chickering and Gamson in science courses. Thus, a mixed method, where quantitative and qualitative research methods were both utilized, was preferred. Mixed method researches are defined as the combination of qualitative and quantitative methods, approaches and concepts in a study or in consecutive studies (Creswell, 2003).

\subsection{Study Group}

The study sample included 113 male and 102 female, a total of 216 science teachers. Include in these subsections.

\subsection{Data Collection Instrument}

"Seven Principles for Good Practice in Undergraduate Education: Faculties Inventory," developed by Chickering and Gamson was translated into Turkish language, adapted to science courses and called "Seven Principles for Good Science Education" by Uğraş (2014). It was determined that the total Cronbach alpha coefficient of the scale was 0.88. Based on this figure, the seven principles for good science education scale can be considered as highly reliable (Kalayci, 2008).

\section{Results}

Based on the recommendations of the field experts, it was decided that if more than $60 \%$ of responses of the participating teachers to all items in 7 principles were 'very frequently' or 'frequently,' it was accepted that the teachers implemented these principles, otherwise, it was interpreted that the teachers did not implement the activities.

Certain participating teacher responses on the first principle, "encourages contacts between students and faculty" were as follows: $59.72 \%$ of science teachers stated that they share their experiences, behavior and values with students; $62.04 \%$ stated that they referred to students by their names after the first two weeks of school; $16,67 \%$ stated that the students came to their offices for visiting purposes only and $34.26 \%$ stated that they would help their students if the students had problems (Table 1).

Below are a few examples of the responses given by the teachers to the questions associated with the first principle in the interviews.

"... Our students at the school usually continue their junior high education after they graduate from the primary school at the premises. Thus, this is not a new school for them and they experience no communications problems with teachers and the school. However, we experience problems with the students who start attending the junior high here. They feel alienated and act shy and cannot communicate with their peers easily in the beginning and that leads to problems in the courses. When that happens, me or other teachers deal with them individually and try to be friendly with these students. We work in coordination with the school guidance counselors to resolve the adaptation problems that these students experience..."

"... We try to establish close relationships with our students as much as possible, because our place of duty is the district center, so the students at our school are friends with one another. Thus, their relationships are generally good, but sometimes the students who joined the school at junior high can experience problems with the old students, but when that happens, the teachers intervene and the problems are resolved..." 
Table1. Percentages and frequencies on the 1st principle

\begin{tabular}{|c|c|c|c|c|c|c|c|c|c|c|c|c|}
\hline \multirow{2}{*}{$\begin{array}{l}\text { Principle 1: Encourages } \\
\text { between students and faculty }\end{array}$} & \multicolumn{2}{|c|}{$\begin{array}{l}\text { Very } \\
\text { Frequently } \\
\end{array}$} & \multicolumn{2}{|c|}{ Frequently } & \multicolumn{2}{|c|}{ Occasionally } & \multicolumn{2}{|c|}{ Seldom } & \multicolumn{2}{|c|}{ Never } & \multicolumn{2}{|c|}{ Total } \\
\hline & $\mathbf{N}$ & $\%$ & $\mathbf{N}$ & $\%$ & $\mathbf{N}$ & $\%$ & $\mathbf{N}$ & $\%$ & $\mathbf{N}$ & $\%$ & $\mathbf{N}$ & $\%$ \\
\hline $\begin{array}{l}\text { 1. I give advice to my students about future } \\
\text { career opportunities. }\end{array}$ & 71 & 32,87 & 40 & 18,52 & 37 & 17,13 & 34 & 15,74 & 34 & 15,74 & 216 & 100 \\
\hline 2. Students come to my office just to visit. & 22 & 10,19 & 14 & 6,48 & 21 & 9,72 & 55 & 25,46 & 104 & 48,15 & 216 & 100 \\
\hline $\begin{array}{l}\text { 3. I share my past experiences, behavior } \\
\text { and values with my students. }\end{array}$ & 82 & 37,96 & 47 & 21,76 & 31 & 14,35 & 29 & 13,43 & 27 & 12,5 & 216 & 100 \\
\hline $\begin{array}{l}\text { 4. I participate in activities organized by } \\
\text { the students. }\end{array}$ & 66 & 30,56 & 40 & 18,52 & 50 & 23,15 & 36 & 16,67 & 24 & 11,1 & 216 & 100 \\
\hline $\begin{array}{l}\text { 5. I discuss in-school and out-of-the-school } \\
\text { experiences of the students with school } \\
\text { administration. }\end{array}$ & 55 & 25,46 & 56 & 25,93 & 45 & 20,83 & 27 & 12,5 & 33 & 15,28 & 216 & 100 \\
\hline $\begin{array}{l}\text { 6. I learn the names of the students after the } \\
\text { first two weeks of the semester and I call } \\
\text { them by their names. }\end{array}$ & 95 & 43,98 & 39 & 18,06 & 44 & 20,37 & 18 & 8,33 & 20 & 9,26 & 216 & 100 \\
\hline $\begin{array}{l}\text { 7. I help my students as a counselor or a } \\
\text { mentor. }\end{array}$ & 65 & 30,09 & 34 & 15,74 & 47 & 21,76 & 31 & 14,35 & 39 & 18,06 & 216 & 100 \\
\hline $\begin{array}{l}\text { 8. I take students to conferences in my field } \\
\text { or in other topics. }\end{array}$ & 47 & 21,76 & 33 & 15,27 & 25 & 11,57 & 20 & 9,27 & 91 & 42,13 & 216 & 100 \\
\hline $\begin{array}{l}\text { 9. When there is a problem at school that is } \\
\text { of interest to the students, I try to help them } \\
\text { to resolve the problem. }\end{array}$ & 51 & 23,61 & 23 & 10,65 & 33 & 15,28 & 57 & 26,39 & 52 & 24,07 & 216 & 100 \\
\hline
\end{tabular}
to resolve the problem.

Based on the responses of the participating teachers to the scale questions, it was determined that the teachers implemented 9 items in the "encourages contacts between students and faculty" very frequently and never implemented one item.

The responses given by the participating teachers in the study on the items associated with the second principle, "develops reciprocity and cooperation among students" were as follows: $68,05 \%$ of the science teachers stated that they distributed the performance assessment criteria to the students to encourage them to share their knowledge, experiences and interests with each other; $59,72 \%$ to encourage them to study together for the courses and exams; $56,48 \%$ to develop projects in collaboration; $46.30 \%$ to allow students to recognize that their grades were independent from the grades of others; and $38.42 \%$ stated that they did not provide incentives to participate in social, cultural and sports activities at school (Table 2).

Table 2. Percentages and frequencies on the 2nd principle

\begin{tabular}{|c|c|c|c|c|c|c|c|c|c|c|c|c|}
\hline \multirow{2}{*}{$\begin{array}{l}\text { Principle 2: Develops reciprocity and } \\
\text { cooperation among students }\end{array}$} & \multicolumn{2}{|c|}{$\begin{array}{l}\text { Very } \\
\text { Frequently }\end{array}$} & \multicolumn{2}{|c|}{ Frequently } & \multicolumn{2}{|c|}{ Occasionally } & \multicolumn{2}{|c|}{ Seldom } & \multicolumn{2}{|c|}{ Never } & \multicolumn{2}{|c|}{ Total } \\
\hline & $\mathrm{N}$ & $\%$ & $\mathrm{~N}$ & $\%$ & $\mathrm{~N}$ & $\%$ & $\mathrm{~N}$ & $\%$ & $\mathrm{~N}$ & $\%$ & $\mathrm{~N}$ & $\%$ \\
\hline $\begin{array}{l}\text { 1. I ask the students to explain themselves } \\
\text { and their interests to each other. }\end{array}$ & 99 & 45,83 & 48 & 22,22 & 26 & 12,04 & 20 & 9,26 & 23 & 10,65 & 216 & 100 \\
\hline $\begin{array}{l}\text { 2. I encourage the students to study together } \\
\text { for the courses or exams. }\end{array}$ & 84 & 38,89 & 45 & 20,83 & 32 & 14,81 & 24 & 11,11 & 31 & 14,35 & 216 & 100 \\
\hline $\begin{array}{l}\text { 3. I ask the students to prepare the projects in } \\
\text { collaboration. }\end{array}$ & 70 & 32,41 & 52 & 24,07 & 36 & 16,67 & 40 & 18,52 & 18 & 8,33 & 216 & 100 \\
\hline $\begin{array}{l}\text { 4. I ask the students to evaluate the work } \\
\text { conducted by other students. }\end{array}$ & 65 & 30,09 & 45 & 20,83 & 46 & 21,3 & 40 & 18,52 & 20 & 9,26 & 216 & 100 \\
\hline $\begin{array}{l}\text { 5. I ask the students to explain difficult topics } \\
\text { to each other. }\end{array}$ & 70 & 32,41 & 40 & 18,52 & 37 & 17,13 & 43 & 19,91 & 26 & 12,04 & 216 & 100 \\
\hline $\begin{array}{l}\text { 6. I ask the students to congratulate each } \\
\text { other's achievements. }\end{array}$ & 59 & 27,31 & 45 & 20,83 & 53 & 24,54 & 33 & 15,28 & 26 & 12,04 & 216 & 100 \\
\hline $\begin{array}{l}\text { 7. I ask the students to discuss important } \\
\text { topics with others with different } \\
\text { perspectives. }\end{array}$ & 72 & 33,33 & 42 & 19,44 & 47 & 21,76 & 32 & 14,81 & 23 & 10,65 & 216 & 100 \\
\hline $\begin{array}{l}\text { 8. I form learning groups, Workgroups or } \\
\text { Project groups in my classes. }\end{array}$ & 65 & 30,09 & 52 & 24,07 & 38 & 17,59 & 45 & 20,83 & 16 & 7,41 & 216 & 100 \\
\hline $\begin{array}{l}\text { 9. I encourage the students to participate at } \\
\text { least one of the different activities organized } \\
\text { by the school. }\end{array}$ & 51 & 23,61 & 32 & 14,81 & 28 & 12,96 & 52 & 24,07 & 53 & 24,54 & 216 & 100 \\
\hline $\begin{array}{l}\text { 10. I distribute answer key and evaluation } \\
\text { criteria to identify that their final grades are }\end{array}$ & 71 & 32,87 & 29 & 13,43 & 46 & 21,3 & 37 & 17,13 & 33 & 15,28 & 216 & 100 \\
\hline
\end{tabular}
independent from the grades of others.

Below are a few examples of the responses given by the teachers to the questions associated with the second principle in the interviews. 
"... Since we work in small towns, there are neighborhood friendships instead of classroom friendships, and when the students start the school, they arrive in a group, which prevents me to form heterogeneous groups. I prefer to assign individual homework, instead of group projects. Since I cannot form the groups the way it should be formed, the studies would not be shared equally and I experience problems in monitoring the outcomes. The students are not aware of the significance of the courses, also environmental factors are active, so my personal efforts did not bear any fruit. I prefer group work in the classroom, because I can continuously follow up these studies. Almost all students are involved in the course during laboratory work, which results in the effective implementation of the curriculum..."

"... The group work is very productive in the 6th and 7 th grades but they prefer to study individually in the 8 th grade due to test anxiety. Our school is a mobile teaching institution. When the group is formed, it is necessary to pay attention to the location of student residences to enable them to conduct studies outside the school as well. It is necessary to forms groups among the students who reside in the villages or in the district. If the student from the village is not successful, the group work fails, reducing the productivity of the group work. I explain the importance of group work before I form the groups in class, and then I form the groups. If there are students in the class who isolate themselves, I try to get them involved more by placing them in better groups..."

Based on the responses of the participating teachers to the scale questions, it was determined that the teachers implemented 8 items out of the 10 items in the "uses active learning techniques" principle very frequently, seldom implemented 1 item and never implemented one item.

The responses given by the participating teachers in the study on the items associated with the third principle, "uses active learning techniques" were as follows: $56.94 \%$ of the participating science teachers stated that they asked the students to present their work in the classroom; 55.09\% stated that they asked the students to explain similarities and differences between scientists and research results; 63.88\% stated that they developed simulations, utilized drama technique or organized related activities in the laboratory frequently for better comprehension of the courses; $42.60 \%$ stated that they organized field trips, various activities or different activities related to the course; and $36.57 \%$ stated that they developed various research projects with the students (Table 3).

Table 3. Percentages and frequencies on the 3rd principle

\begin{tabular}{|c|c|c|c|c|c|c|c|c|c|c|c|c|}
\hline \multirow[t]{2}{*}{ Principle 3: Uses active learning techniques } & \multicolumn{2}{|c|}{$\begin{array}{l}\text { Very } \\
\text { Frequently }\end{array}$} & \multicolumn{2}{|c|}{ Frequently } & \multicolumn{2}{|c|}{ Occasionally } & \multicolumn{2}{|c|}{ Seldom } & \multicolumn{2}{|c|}{ Never } & \multicolumn{2}{|c|}{ Total } \\
\hline & $\mathrm{N}$ & $\%$ & $\mathrm{~N}$ & $\%$ & $\mathrm{~N}$ & $\%$ & $\mathrm{~N}$ & $\%$ & $\mathrm{~N}$ & $\%$ & $\mathrm{~N}$ & $\%$ \\
\hline $\begin{array}{l}\text { 1. I ask the students to explain and present } \\
\text { their work in the classroom. }\end{array}$ & 123 & 56,94 & 29 & 13,43 & 25 & 11,57 & 18 & 8,33 & 21 & 9,72 & 216 & 100 \\
\hline $\begin{array}{l}\text { 2. I ask the students to explain similarities and } \\
\text { differences between scientists and research } \\
\text { results. }\end{array}$ & 68 & 31,48 & 51 & 23,61 & 36 & 16,67 & 33 & 15,28 & 28 & 12,96 & 216 & 100 \\
\hline $\begin{array}{l}\text { 3. I ask the students to relate an event or } \\
\text { activity they experienced in Daily life with } \\
\text { the topics instructed in the courses. }\end{array}$ & 64 & 29,63 & 42 & 19,44 & 47 & 21,76 & 36 & 16,67 & 27 & 12,50 & 216 & 100 \\
\hline $\begin{array}{l}\text { 4. I ask the students to take responsibility in a } \\
\text { research or an independent study. }\end{array}$ & 81 & 37,5 & 42 & 19,44 & 41 & 18,98 & 26 & 12,04 & 26 & 12,04 & 216 & 100 \\
\hline $\begin{array}{l}\text { 5. I encourage the students to object my ideas, } \\
\text { ideas of their peers and the topics they read of } \\
\text { instructed in the courses. }\end{array}$ & 74 & 34,26 & 48 & 22,22 & 40 & 18,52 & 29 & 13,43 & 25 & 11,57 & 216 & 100 \\
\hline $\begin{array}{l}\text { 6. I give concrete and real-life examples for } \\
\text { the students to develop better analysis skills. }\end{array}$ & 75 & 34,72 & 40 & 18,52 & 52 & 24,07 & 23 & 10,65 & 26 & 12,04 & 216 & 100 \\
\hline $\begin{array}{l}\text { 7. I develop simulations, utilize drama } \\
\text { techniques or conduct applications in the } \\
\text { laboratory for the students to comprehend the } \\
\text { courses better. }\end{array}$ & 96 & 44,44 & 42 & 19,44 & 30 & 13,89 & 27 & 12,5 & 21 & 9,72 & 216 & 100 \\
\hline $\begin{array}{l}\text { 8. I expect the students to propose new texts, } \\
\text { new research projects, new field trips and } \\
\text { course activities. }\end{array}$ & 69 & 31,94 & 39 & 18,06 & 37 & 17,13 & 35 & 16,2 & 36 & 16,67 & 216 & 100 \\
\hline $\begin{array}{l}\text { 9. We organize field trips, various activities or } \\
\text { different course-related activities in } \\
\text { collaboration with the students. }\end{array}$ & 53 & 24,54 & 39 & 18,06 & 32 & 14,81 & 24 & 11,11 & 68 & 31,48 & 216 & 100 \\
\hline $\begin{array}{l}\text { 10. We develop various research projects in } \\
\text { collaboration with the students. }\end{array}$ & 47 & 21,76 & 32 & 14,81 & 44 & 20,37 & 51 & 23,61 & 42 & 19,44 & 216 & 100 \\
\hline
\end{tabular}

Below are a few examples of the responses given by the teachers to the questions associated with the third principle in the interviews. 
"... I usually use the lab in science classes. Because, the scientific topics are abstract, it is difficult for the students to perceive these topics. I try to concretize the subject content. For instance, I conduct experiments on buoyancy, which is difficult for the students to comprehend. I ask the students what would happen before placing an object in a container filled with water and I listen to their ideas then I place the object and ask them to interpret the changes and explain why that happened. That way, the students participate in the class more willingly."

"... I often try to explain chemistry topics with experiments. But before I start the experiment, I do things that would surprise students and pay attention, for example, in the chemical reactions topic, I add sugar and then sulfuric acid to potassium chlorate and let them watch the fireballs. When I do that, the students become more enthusiastic and pat attention and participate in the class. I prefer to introduce the topic with interesting facts that would attract their attention. Otherwise, it becomes difficult for the students to actively participate in the class. Because, most students are prejudiced against science, but succeed with the methods mentioned above. I observe this due to their participation in the class, their achievements in the in-classroom activities and the increased success rate in the external prep tests that my senior students take..."

Based on the responses of the participating teachers to the scale questions, it was determined that the teachers implemented 7 items out of the 10 items in the "gives prompt feedback" principle very frequently, implemented 1 item frequently, seldom implemented 1 item and never implemented one item.

The responses given by the participating teachers in the study on the items associated with the fourth principle, "gives prompt feedback" were as follows: $60.65 \%$ of the participating science teachers stated that they assigned homework to the students and conducted tests; $53.46 \%$ stated that they asked the students to discuss their development; $43,05 \%$ stated that they tested the students at the beginning of the semester to determine their prior knowledge; $50 \%$ stated that the communicated with absentee students either directly or via messengers; $48.61 \%$ stated that they explained how the evaluations on the course would be conducted in detail at the beginning of the semester (Table 4).

Table 4. Percentages and frequencies on the 4 th principle

\begin{tabular}{|c|c|c|c|c|c|c|c|c|c|c|c|c|}
\hline \multirow[t]{2}{*}{ Principle 4: Gives prompt feedback } & \multicolumn{2}{|c|}{$\begin{array}{l}\text { Very } \\
\text { Frequently }\end{array}$} & \multicolumn{2}{|c|}{ Frequently } & \multicolumn{2}{|c|}{ Occasionally } & \multicolumn{2}{|c|}{ Seldom } & \multicolumn{2}{|c|}{ Never } & \multicolumn{2}{|c|}{ Total } \\
\hline & $\mathrm{N}$ & $\%$ & $\mathrm{~N}$ & $\%$ & $\mathrm{~N}$ & $\%$ & $\mathrm{~N}$ & $\%$ & $\mathrm{~N}$ & $\%$ & $\mathrm{~N}$ & $\%$ \\
\hline 1. I assign homework and test the students. & 95 & 43,98 & 36 & 16,67 & 35 & 16,2 & 31 & 14,35 & 19 & 8,80 & 216 & 100 \\
\hline $\begin{array}{l}\text { 2. I prepare questions or organize various } \\
\text { class activities to receive prompt feedback } \\
\text { from the students. }\end{array}$ & 78 & 36,11 & 40 & 18,52 & 41 & 18,98 & 32 & 14,81 & 25 & 11,57 & 216 & 100 \\
\hline $\begin{array}{l}\text { 3. I grade student tests or similar documents } \\
\text { within a week. }\end{array}$ & 46 & 21,3 & 54 & 25 & 50 & 23,15 & 28 & 12,96 & 38 & 17,59 & 216 & 100 \\
\hline $\begin{array}{l}\text { 4. I explain how I would conduct course } \\
\text { evaluations in detail at the beginning of each } \\
\text { semester. }\end{array}$ & 58 & 26,85 & 47 & 21,76 & 63 & 29,17 & 27 & 12,5 & 21 & 9,72 & 216 & 100 \\
\hline $\begin{array}{l}\text { 5. I ask the students to talk with me about their } \\
\text { self-development. }\end{array}$ & 75 & 34,72 & 34 & 15,74 & 47 & 21,76 & 24 & 11,11 & 36 & 16,67 & 216 & 100 \\
\hline $\begin{array}{l}6 \text {. I notify the students their strengths and } \\
\text { weaknesses in exams and similar activities in } \\
\text { writing. }\end{array}$ & 55 & 25,46 & 44 & 20,37 & 39 & 18,06 & 44 & 20,37 & 34 & 15,74 & 216 & 100 \\
\hline $\begin{array}{l}\text { 7. I test the preliminary knowledge of the } \\
\text { students at the beginning of every semester. }\end{array}$ & 61 & 28,24 & 32 & 14,81 & 42 & 19,44 & 32 & 14,81 & 49 & 22,69 & 216 & 100 \\
\hline $\begin{array}{l}\text { 8. I ask the students to record and monitor } \\
\text { their achievements and development. }\end{array}$ & 56 & 25,93 & 36 & 16,67 & 52 & 24,07 & 41 & 18,98 & 31 & 14,35 & 216 & 100 \\
\hline $\begin{array}{l}\text { 9. I evaluate the final exam results in } \\
\text { collaboration with the students. }\end{array}$ & 67 & 31,02 & 28 & 12,96 & 56 & 25,93 & 33 & 15,28 & 32 & 14,81 & 216 & 100 \\
\hline $\begin{array}{l}\text { 10. I call absentee students or communicate } \\
\text { with them with a messenger. }\end{array}$ & 72 & 33,33 & 36 & 16,67 & 45 & 20,83 & 24 & 11,11 & 39 & 18,06 & 216 & 100 \\
\hline
\end{tabular}

Below are a few examples of the responses given by the teachers to the questions associated with the fourth principle in the interviews.

"...Normally, I would prefer to conduct the activities that needs to be conducted at the end of a topic, assessment questions and, if possible, performance assignments in the classroom, because I think it would be healthier to identify and correct the shortcomings and improve the performance of the students within the process, I cannot conduct all these activities properly, since they need to be completed within the time allotted for the class. And since project homework should be completed within a certain period of time, sometimes the students come to my office for advice and sometimes I ask them how they are doing with 
the homework."

"... I ask the groups to make presentations on their work in certain intervals to monitor their development in project assignments. I ask a random student within the group to give the presentation, so everyone in the group would spend an effort for the assignment. However, I cannot do that for every group because the time is very limited ..."

Based on the responses of the participating teachers to the scale questions, it was determined that the teachers implemented 7 items out of the 8 items in the "emphasizes time on task" principle very frequently and seldom implemented 1 item.

The responses given by the participating teachers in the study on the items associated with the fifth principle, "emphasizes time on task" were as follows: $61.57 \%$ of the participating teachers stated that they asked the students to complete their homework on time; 50,47\% stated that they notified the students for absenteeism; $51,86 \%$ stated that they discussed studying habits, study plans and other habits with students with low achievement; 39,36\% stated that they asked the students who missed classes to compensate for it (Table 5).

Table 5. Percentages and frequencies on the 5th principle

\begin{tabular}{|c|c|c|c|c|c|c|c|c|c|c|c|c|}
\hline \multirow{2}{*}{ Principle 5: Emphasizes time on task } & \multicolumn{2}{|c|}{$\begin{array}{l}\text { Very } \\
\text { Frequently }\end{array}$} & \multicolumn{2}{|c|}{ Frequently } & \multicolumn{2}{|c|}{ Occasionally } & \multicolumn{2}{|c|}{ Seldom } & \multicolumn{2}{|c|}{ Never } & \multicolumn{2}{|c|}{ Total } \\
\hline & $\mathrm{N}$ & $\%$ & $\mathrm{~N}$ & $\%$ & $\mathrm{~N}$ & $\%$ & $\mathrm{~N}$ & $\%$ & $\mathrm{~N}$ & $\%$ & $\mathrm{~N}$ & $\%$ \\
\hline $\begin{array}{l}\text { I ask the students to complete their } \\
\text { homework on time. }\end{array}$ & 106 & 49,07 & 27 & 12,5 & 39 & 18,06 & 24 & 11,11 & 20 & 9,26 & 216 & 100 \\
\hline $\begin{array}{l}\text { I explain the students how long it should } \\
\text { take for them to comprehend the assigned } \\
\text { complex material based on their levels. }\end{array}$ & 75 & 34,72 & 43 & 19,91 & 35 & 16,2 & 17 & 7,87 & 46 & 21,30 & 216 & 100 \\
\hline $\begin{array}{l}\text { I help the students to determine attainable } \\
\text { and high goals. }\end{array}$ & 68 & 31,48 & 28 & 12,96 & 53 & 24,54 & 29 & 13,43 & 38 & 17,59 & 216 & 100 \\
\hline $\begin{array}{l}\text { I encourage the students during oral exams } \\
\text { and in-classroom presentations. }\end{array}$ & 66 & 30,56 & 51 & 23,61 & 54 & 25 & 17 & 7,87 & 28 & 12,96 & 216 & 100 \\
\hline $\begin{array}{l}\text { I emphasize the significance of studying } \\
\text { regularly and with a plan and practical and } \\
\text { vocal repetition. }\end{array}$ & 84 & 38,89 & 31 & 14,35 & 55 & 25,46 & 21 & 9,722 & 25 & 11,57 & 216 & 100 \\
\hline $\begin{array}{l}\text { I notify the students about their } \\
\text { absenteeism. }\end{array}$ & 73 & 33,8 & 36 & 16,67 & 58 & 26,85 & 30 & 13,89 & 19 & 8,80 & 216 & 100 \\
\hline $\begin{array}{l}\text { I discussed studying habits, study plans and } \\
\text { other habits with students with low } \\
\text { achievement. }\end{array}$ & 66 & 30,56 & 46 & 21,3 & 39 & 18,06 & 29 & 13,43 & 36 & 16,67 & 216 & 100 \\
\hline $\begin{array}{l}\text { I ask the students who missed classes to } \\
\text { compensate for it. }\end{array}$ & 46 & 21,3 & 39 & 18,06 & 58 & 26,85 & 33 & 15,28 & 40 & 18,52 & 216 & 100 \\
\hline
\end{tabular}

Below are a few examples of the responses given by the teachers to the questions associated with the fifth principle in the interviews.

"... I narrate an anecdote on 'time is cash' on the first day of classes. It goes like this; the grandfather asks his grandson whether he prefers time or cash. Since the grandson is very wise, he immediately says 'time' and continues: time is more important because you can use time to earn cash, but you cannot buy time with cash. I then ask the students about the moral of the anecdote and I allow them to discuss on the matter and deduct ideas I always remind them of the anecdote during instructions and I ask them to use the time they are in better..."

"... When I feel that my students are not interested in the topics at hand, I pause instruction and try to talk to them. I use my previous students as examples, I tell them they thought that the school will not be over and they would stay students forever, however they realized after graduation that the time passed by, but it was too late. Then I ask them to tackle their courses because that is their most important task in the present, otherwise they could join the mistakes of my previous students and end up sad like they did. And then I listen to their views and reemphasize the importance of time. And tell them that all tasks should be 
completed in a timely and efficient manner. After I discuss these matters, I observe that the students concentrate better when I go back to the instruction..."

Based on the responses of the participating teachers to the scale questions, it was determined that the teachers implemented 9 out of the 10 items in the "communicates high expectations" principle very frequently and seldom implemented 1 item.

The responses given by the participating teachers in the study on the items associated with the sixth principle, "communicates high expectations" were as follows: $54.17 \%$ of the participating science teachers stated that they expected the students to work hard; $68.98 \%$ stated that they notified the achievements they expected from the students in verbal and written forms at the beginning of the semester; 55.56\% stated that they regularly discussed how to improve the course instructions with the students, and $38.89 \%$ stated that they clearly explained that they expected excellent performance from the students (Table 6).

Table 6. Percentages and frequencies on the 6th principle

\begin{tabular}{|c|c|c|c|c|c|c|c|c|c|c|c|c|}
\hline \multirow{2}{*}{$\begin{array}{l}\text { Principle 6: Communicates high } \\
\text { expectations }\end{array}$} & \multicolumn{2}{|c|}{$\begin{array}{l}\text { Very } \\
\text { Frequently }\end{array}$} & \multicolumn{2}{|c|}{ Frequently } & \multicolumn{2}{|c|}{ Occasionally } & \multicolumn{2}{|c|}{ Seldom } & \multicolumn{2}{|c|}{ Never } & \multicolumn{2}{|c|}{ Total } \\
\hline & $\mathrm{N}$ & $\%$ & $\mathrm{~N}$ & $\%$ & $\mathrm{~N}$ & $\%$ & $\mathrm{~N}$ & $\%$ & $\mathrm{~N}$ & $\%$ & $\mathrm{~N}$ & $\%$ \\
\hline $\begin{array}{l}\text { 1. I explain the students that I expect them to } \\
\text { work hard in my class. }\end{array}$ & 63 & 29,17 & 54 & 25 & 46 & 21,3 & 25 & 11,57 & 28 & 12,96 & 216 & 100 \\
\hline $\begin{array}{l}\text { 2. I emphasize that the students need to } \\
\text { sustain a level to become successful. }\end{array}$ & 76 & 35,19 & 37 & 17,13 & 41 & 18,98 & 23 & 10,65 & 39 & 18,06 & 216 & 100 \\
\hline $\begin{array}{l}\text { 3. I notify the students about the } \\
\text { achievements I expected from them in } \\
\text { verbal and written forms at the beginning of } \\
\text { the semester. }\end{array}$ & 113 & 52,31 & 36 & 16,67 & 32 & 14,81 & 20 & 9,259 & 15 & 6,94 & 216 & 100 \\
\hline $\begin{array}{l}\text { 4. I assist the students to identify goals } \\
\text { adequate for their levels. }\end{array}$ & 84 & 38,89 & 42 & 19,44 & 48 & 22,22 & 19 & 8,796 & 23 & 10,65 & 216 & 100 \\
\hline $\begin{array}{l}\text { 5. I explain my students the consequences of } \\
\text { not completing their tasks on time. }\end{array}$ & 62 & 28,7 & 50 & 23,15 & 46 & 21,3 & 25 & 11,57 & 33 & 15,28 & 216 & 100 \\
\hline $\begin{array}{l}\text { 6. I suggest the students to conduct } \\
\text { extensive extracurricular reading and } \\
\text { writing studies. }\end{array}$ & 62 & 28,7 & 46 & 21,3 & 50 & 23,15 & 26 & 12,04 & 32 & 14,81 & 216 & 100 \\
\hline $\begin{array}{l}\text { 7. I encourage the students to conduct } \\
\text { extensive writing studies. }\end{array}$ & 75 & 34,72 & 36 & 16,67 & 50 & 23,15 & 31 & 14,35 & 24 & 11,11 & 216 & 100 \\
\hline $\begin{array}{l}\text { 8. I clearly state to the students that I expect } \\
\text { excellent performance from them. }\end{array}$ & 49 & 22,69 & 35 & 16,2 & 54 & 25 & 37 & 17,13 & 41 & 18,98 & 216 & 100 \\
\hline $\begin{array}{l}\text { 9. I regularly update the course information } \\
\text { for my classes. }\end{array}$ & 67 & 31,02 & 41 & 18,98 & 40 & 18,52 & 31 & 14,35 & 37 & 17,13 & 216 & 100 \\
\hline $\begin{array}{l}\text { 10. I regularly discuss with the students on } \\
\text { how to instruct the course better from the }\end{array}$ & 93 & 43,06 & 27 & 12,5 & 45 & 20,83 & 21 & 9,722 & 30 & 13,89 & 216 & 100 \\
\hline
\end{tabular}
beginning of the semester.

Below are a few examples of the responses given by the teachers to the questions associated with the sixth principle in the interviews.

"... On my first class, I ask the students what they want to do when they grow up. When their reposes are science-related, I try to explain them how to approach science. For the students who are willing to cope with their shortcomings in science, I organize out-of-the-classroom study hours and allow them to work towards their goals..."

"... I notice that almost all students are biased against the course at the beginning of the semester. When I ask, some even admit that they do not like the science course. I observe that this bias disappears in most students after the educational and instructional process during the semester. Their participation in the class, their enthusiasm about the activities make me feel that I do the right thing in the process. Among the students who had ideas not related to scientific fields, there are those who want to be chemists in the future due to the enjoyable classes in the lab, also others, who want to become biologists due to the animations in the interactive CDs we watch..."

Based on the responses of the participating teachers to the scale questions, it was determined that the teachers implemented 8 out of the 9 items in the "respects diverse talents and ways of learning" principle very frequently and seldom implemented 1 item.

The responses given by the participating teachers in the study on the items associated with the sixth principle, "respects diverse talents and ways of learning" were as follows: $66.61 \%$ of the participating science teachers stated that they 
encouraged the students to ask questions about the topics they did not comprehend; 40,74\% stated that they sometimes provided information about gender and different cultures to the students (Table 7).

Table 7. Percentages and frequencies on the 7 th principle

\begin{tabular}{|c|c|c|c|c|c|c|c|c|c|c|c|c|}
\hline \multirow{2}{*}{$\begin{array}{l}\text { Principle } 7 \text { : Respects diverse talents and } \\
\text { ways of learning }\end{array}$} & \multicolumn{2}{|c|}{$\begin{array}{l}\text { Very } \\
\text { Frequently } \\
\end{array}$} & \multicolumn{2}{|c|}{ Frequently } & \multicolumn{2}{|c|}{ Occasionally } & \multicolumn{2}{|c|}{ Seldom } & \multicolumn{2}{|c|}{ Never } & \multicolumn{2}{|c|}{ Total } \\
\hline & $\mathrm{N}$ & $\%$ & $\mathrm{~N}$ & $\%$ & $\mathrm{~N}$ & $\%$ & $\mathrm{~N}$ & $\%$ & $\mathrm{~N}$ & $\%$ & $\mathrm{~N}$ & $\%$ \\
\hline $\begin{array}{l}\text { 1. I encourage the students to easily ask me } \\
\text { about the topics they did not comprehend. }\end{array}$ & 105 & 48,61 & 39 & 18,06 & 36 & 16,67 & 17 & 7,87 & 19 & 8,80 & 216 & 100 \\
\hline $\begin{array}{l}\text { 2. I do not allow belittling jokes and similar } \\
\text { behavior that could humiliate the students. }\end{array}$ & 103 & 47,69 & 39 & 18,06 & 31 & 14,35 & 20 & 9,259 & 23 & 10,65 & 216 & 100 \\
\hline $\begin{array}{l}\text { 3. I use various instructional methods and } \\
\text { techniques that could address all students. }\end{array}$ & 84 & 38,89 & 25 & 11,57 & 37 & 17,13 & 31 & 14,35 & 39 & 18,06 & 216 & 100 \\
\hline $\begin{array}{l}\text { 4. I organize different reading amd similar } \\
\text { activities that are adequate for the student } \\
\text { knowledge. }\end{array}$ & 60 & 27,78 & 43 & 19,91 & 49 & 22,69 & 30 & 13,89 & 34 & 15,74 & 216 & 100 \\
\hline $\begin{array}{l}\text { 5. I utilize additional material and conduct } \\
\text { applications for the students with } \\
\text { inadequate knowledge. }\end{array}$ & 56 & 25,93 & 48 & 22,22 & 48 & 22,22 & 35 & 16,2 & 29 & 13,43 & 216 & 100 \\
\hline $\begin{array}{l}\text { 6. I provide information to the students on } \\
\text { gender issues and individuals with different } \\
\text { cultures. }\end{array}$ & 46 & 21,3 & 42 & 19,44 & 53 & 24,54 & 40 & 18,52 & 35 & 16,20 & 216 & 100 \\
\hline $\begin{array}{l}\text { 7. I help students who desire individual } \\
\text { studies in my courses or in others. }\end{array}$ & 61 & 28,24 & 55 & 25,46 & 40 & 18,52 & 37 & 17,13 & 23 & 10,65 & 216 & 100 \\
\hline $\begin{array}{l}\text { 8. I develop alternative methods and } \\
\text { techniques such as mastery learning or } \\
\text { different learning methods in my classes. }\end{array}$ & 62 & 28,7 & 55 & 25,46 & 49 & 22,69 & 27 & 12,5 & 23 & 10,65 & 216 & 100 \\
\hline $\begin{array}{l}\text { 9. I encourage the students to study the } \\
\text { topics they are interested in. }\end{array}$ & 84 & 38,89 & 46 & 21,3 & 34 & 15,74 & 28 & 12,96 & 24 & 11,11 & 216 & 100 \\
\hline
\end{tabular}

Below are a few examples of the responses given by the teachers to the questions associated with the seventh principle in the interviews.

"... I can keep in touch with the students who are successful in science in the classroom, they might have problems or topics that they did not comprehend; I try to help them between the classes. But I do not have the opportunity to assist the unsuccessful students one-on-one, because the curriculum is very wide, and whether I like it or not, I have to instruct the whole curriculum. At the beginning of the semester I tried different methods so that all could comprehend the topics, but then the students who comprehended the topic on the first sty started to complain, when I implemented different methods, the time allotted for the class fell short and we could not complete the instruction; now I still try to implement different methods, but I cannot do something different to make all to comprehend the subject..."

"... My classroom is not very crowded, so I can scrutinize the things the pupils do not comprehend by repetitions frequently even though the curriculum is extensive. I often have non-problematic and fruitful classes with my students because they like the science course..."

\section{Discussion}

The present study aimed to determine the perceptions of science teachers on the implementation of the seven principles for good practice in education developed by Chickering and Gamson. In line with this aim, qualitative data were collected from science teachers using the survey form and interviews.

The interpretation of the data obtained to determine the level of implementation of the seven principles that Chickering and Gamson proposed for good practice in education by science teachers in their classes was conducted separately for each principle and presented in the following order.

It was determined that the mean frequency of the implementation of the items in the first principle called "encourages contacts between students and faculty" by science teachers was 3.14. Based on this general average, it was concluded that the participating science teachers occasionally implemented the items on the development of the contacts between the students and the faculty.

Based on the responses given to the items related to the first principle, it was determined that most teachers did not participate in the activities organized by the students, did not advice the students, did not take the students to meetings related to their field or other subjects. The points mentioned in these items are significant for the teachers to give the students the impression that they care about them. Furthermore, their participation in these events may allow them to spend more time with the students and establish better contact. The strong bond that would be formed as a result could 
improve the students' achievements in science classes. It is very important for teachers to guide their students and to provide recommendations. Teachers' interest in the lives of their students and recommendations would affect the students positively. Thus, they can succeed both in their courses and lives.

In interviews conducted with teachers, they stated that the students from small towns are introvert and when they exhibit interest in the students, in certain cases they would succeed to overcoming this issue, and in other they might not. Due to the lack of guidance counselor at the school, they are never sure how to behave with such students, they fail to establish warm relationships with male students with problems, they principally experienced problems with students transported from distant locations and they could not monitor the students individually due to high class population. Generally, it was determined that the science teachers spent efforts to establish a warm relationship between the students and the faculty, however failed to reach the desired outcome due to the reasons mentioned above.

Literature review demonstrated that the most important factor in the development of students' sense of belonging to the school is the quality of the relationship between teachers and students (Beck and Malley, 1998). It was stated that the belongingness of the students to their class and the school is very important in establishing a successful learning community and thus a successful learning process. It is also mentioned in the literature that traditional in-classroom practices prevent the development of student belomgingness (Beck and Malley, 1998). It was suggested that the belongingness of the students to the school can be improved by creating a learning environment that would enable students to have positive and supportive social interaction among themselves and with their teachers (Burden, 2003). Similarly, it was stated that the learning community, which is the result of high cooperation among the students in the class enabled by the teachers, presence of the supportive role of the teachers, and allow the students to have the feeling of mutual respect and acceptance and create social relations with the pupils, would improve the students' sense of belonging (Cangelosi, 2004, Cox, Duncheon and McDavid, 2009; Jennings and Greenberg, 2009; Jones and Jones, 1998).

It was determined that the mean frequency of the implementation of the items in the second principle called "develops reciprocity and cooperation among students" by science teachers was 3.43 . Based on this average, it was concluded that the participating science teachers frequently implemented the items on the cooperation among the students.

Based on the responses given to the items related to the principle of developing reciprocity and cooperation among students, it was determined that most science teachers did not advice the students to congratulate each other's achievements. Teachers should indicate to the students that competition is fine up to a certain level, however if they go too far, they can face negative consequences. Furthermore, they should tell the students that it is a proper behavior to congratulate their successful peers and they should be happy for the achievements of their friends. In order to increase the in-classroom or out-of-the-classroom cooperation among the students, it is also necessary to allow the students to work in groups during the organization of the activities, performances and project assignments. Students share their responsibilities while conducting research for the assignments or preparing the assignments. Since their grades would be the same for the assignments, group members would collaborate and help each other more. This would increase the cooperation and reciprocity among the students. Furthermore, social clubs that are not used effectively in Turkish schools aim to improve cooperative social responsibilities. Improving the functions of social clubs at schools would greatly benefit the development of cooperation among the students.

As a result of the interviews conducted with science teachers, it was determined that teachers spent effort to improve cooperation among students by including group work continuously in science classes, changing the location of the group members in group work, spending time with student groups outside the classroom, assigning active tasks to students in the lab classes and in the instruction process and conducting similar activities, and thus considered that they contributed to the improvement of cooperation among the students.

Literature review indicates that collaborative learning-based education improves the academic achievements of students. This increase in achievements is attributed to the fact that students can easily express their ideas, share their thoughts with others, and encourage each other by cooperating with the group members (Abdullah and Shariff, 2008; Acar and Tarhan, 2008; Aksoy, 2011; Artut and Tarim, 2007; Doymus, 2008; Lai and Wu, 2006; Souvignier and Kronenberger, 2007).

Based on their responses, it was determined that the mean frequency of the implementation of the items in the "uses active learning techniques" principle by science teachers was 3.44. Based on this average, it was concluded that the participating science teachers frequently implemented the items that were effective on the use of active learning techniques.

It was determined that most science teachers participating in the study were not able to help the students to associate the daily life events with the instruction topics and hence, could not implement the related item in the "uses active learning techniques" principle. However, association of the daily life events with the instruction topics would help the students 
to comprehend the significance of the topics. Instruction of abstract knowledge by comparing the phenomenon with daily life examples rather than leaving the student to make sense of the instruction would facilitate the understanding of the student and increase the degree of success. For example, during the instruction of transparent and opaque objects, instead of explaining the first is an object that allows the light to pass through and the latter does not, it is better to explain that opaque is like the walls of our homes that prevent our rooms and classrooms to be seen from the street and the house and school windows are made of glass, which is a transparent material, allowing the sunlight to shine through. Thus, it would make a better sense for the student, and the student would comprehend the subject better. It was also determined that teachers did not recommend new research projects, new field trips or class activities. Asking pupils to prepare new projects, recommend new field trips or classroom activities would allow them to conduct research. Thus, they would acquire the habit of conducting research, one of the properties of science literate individuals. It was also determined that teachers did not organize field trips, various activities or classroom activities with the students, and did not develop collaborative projects. Spending extra time with the students, conducting both cultural and scientific activities with the students would lead to better relationships and bonds between the teachers and the students. In projects conducted with teachers, students would be more involved and could easily reach the desired achievement levels. Thus, it is considered that teachers should engage in different activities with the students and that would be good for their development.

Interviews conducted with teachers demonstrated that the instructed the courses by allowing the student to interpret lab results, to organize activities related to the course topics, to design material, to give examples from daily activities associated with the instructed topic and thus, allowing the students to participate in the active learning process.

It was determined that the academic achievements of the students increased in science courses and in others as a result of using active learning methods (Akpınar, 2003; Uysal, 1996; Sezgin Memnun, 2003; Çullu, 2003; Rosenthal, 1995; Parvin, 1984; Mertoğlu, 2002; Şahinel, 2003). In a study conducted by Seyhan and Gür (2002), the students stated that they preferred the instruction of the courses with the active learning approach since they believed they would be more successful.

Based on their responses, it was determined that the mean frequency of the implementation of the items in the "gives prompt feedback" principle by science teachers was 3.34. Based on this average, it was concluded that the participating science teachers seldom implemented the items that were effective on providing prompt feedback.

It was determined that most science teachers participating in the study were not able to grade the exams in a short period of time and hence, could not implement the related item in the "gives prompt feedback" principle. It was determined that they did not provide detailed information on the course assessment, did not report the weaknesses and strengths of the students in the exams, did not test the students to determine their preliminary knowledge, and did not record the student achievements and progress. Feedback, and especially prompt feedback is significant for the permanence of the education. Feedback could be given after the assessment activities and during the instruction of the course. Especially after the instruction of the topic, it is very important for accurate learning of the topic and permanence of the knowledge to ask questions about the subject and providing feedback about the student responses, correcting the inaccurate information while the information is still fresh. Measurement and evaluation activities should serve more to provide the missing information instead of grading the students. After the measurement and evaluation activities, it would be better for the improvement of student achievements to grade the examinations promptly, determine the students' mistakes and remove their weaknesses.

Based on the interviews conducted with the teachers on this item, they stated that it was not possible to observe and assess all the students due to limited weekly course hours for the science class and high class population, and also they were not able to assess the group members adequately since the group assignments were completed at home.

In the literature, it was stated that feedback is the most important element in the educational process (Bloom, 1979). In a study by Block (1979), it was found that the control group students, who did not receive feedback and corrective processes, could only get an average of $50 \%$ of the maximum points in the formative tests applied at the end of each learning unit. On the other hand, the students in the full learning group, who received feedback and corrections, scored $90 \%$ of the highest possible points on the same formative tests (Cited by Bloom, 1980). In studies conducted by Yunt (1978), Senemoğlu (1987) and Peker (1992), the effects of feedback and correction on the academic achievements of the students were investigated. The findings demonstrated that feedback and correction contributed significantly to the overall achievements of the students.

Based on their responses, it was determined that the mean frequency of the implementation of the items in the "emphasizes time on task" principle by science teachers was 3.44. Based on this average, it was concluded that the participating science teachers frequently implemented the items that were effective on emphasizing time on tasks.

It was determined that the science teachers participating in the study did not help the students to set higher goals and did 
not ask the absentee students to compensate the classes they missed as determined by the "emphasizes time on task" principle. On time completion of the daily research assignments and homework assigned for reinforcement of the topics would significantly affect their achievements. Failure to complete research assignments on time that aim to improve the readiness of the students when they arrive at the classroom and to facilitate the internalization of the topic would affect the achievements of the students, failure to complete the reinforcement activities on time, which are an important part of the out-of-the-classroom education, would adversely affect the student. Furthermore, time on task is directly related to the student responsibility and would affect the student directly on every stage of life. It is therefore beneficial for teachers to be sensitive about time on task both to improve the educational achievements of the students and to acquire the habit of fulfilling their responsibilities.

Based on the interviews conducted with the teachers, they stated that they talked with the students about the significance of time, communicated their own experiences with the students to establish an important awareness of time, and thus the tasks were completed on time as a result. Furthermore, the fact that some teachers stated that the grades would be lower if the students submit their assignments later than the deadline contributed to the timely completion of assignments by the students.

Previous studies were conducted on assigning homework to the students to create and improve their sense of responsibility. The abovementioned studies demonstrated that the participating students' sense of responsibility developed in these studies (Johnson and Pontius, 1989). In a study conducted by Muhlenbruk et al. (2000), it was reported that homework was assigned to students to improve their ability to use time effectively, and there were significant changes in the effective use of time among the students as a result. It was found that as the time students spend to complete science assignments increased, their achievements in the course increases as well (Beaton et al., 1996; Postlethwaite \& Wiley, 1992).

Based on their responses, it was determined that the mean frequency of the implementation of the items in the "communicates high expectations" principle by science teachers was 3.44. Based on this average, it was concluded that the participating science teachers frequently implemented the items that were effective on communicating high expectations.

It was determined that most participating science teachers did not communicate their high expectations to the students as stated in the abovementioned principle.

The most important task for teachers in educational and instructional activities is to guide students. In fulfilling this function, teachers need to be clear and open to their students. As a result, students and teachers would understand each other better, know each other's expectations and conduct the activities necessary to meet these expectations. Teachers are required to help students to develop their self-confidence and keep their goals at the highest level. It is also important for the students to feel that their teachers are always on their side.

In the interviews conducted with the teachers, when they were asked how they communicated high expectations, the teachers stated that they always took care of the students on out-of-class topics as well and made sure that students with different goals would love science and target scientific professions as a result of various methods and strategies they adopted during the instruction process and accomplished the task by explaining the importance of science in our lives.

In the literature, it was also stated that the teachers had a significant impact on the career choices of the students (Yanikkerem et al., 2004; Sarikaya and Khorshid, 2009).

Based on their responses, it was determined that the mean frequency of the implementation of the items in the "respects diverse talents and ways of learning" principle by science teachers was 3.48. Based on this average, it was concluded that the participating science teachers frequently implemented the items in the "respects diverse talents and ways of learning" principle.

It was determined that most science teachers participated in the study did not provide information to the students on individuals with a different gender and cultures. Students possess different areas of intelligence, and as a result, they can learn with the help of different methods and techniques. It is important for teachers to conduct different instructional activities in and out of the classroom based on their learning areas of the students, to conduct additional work with students with different learning speed, and to be open to alternative learning activities at all times to improve student achievements.

In the interviews conducted with the science teachers, they were asked how they conducted a good practice in science education. Teachers stated that they conducted good science education practices by frequently repeating the instructions in the classroom and asking the students questions on the current subject, by conducting study hours outside the regular schedule, by utilizing technologies when instructing the topics, by allowing the students to watch related videos, by conducting activities included in the guide book and related to daily events, by taking individual care of the students 
with poor students to remove their prejudice against sciences and by communicating with student parents.

For good practice in science education, Demirbaş and Yağbasan (2005) stated that laboratory facilities should be made available, technological developments should be reflected on the educational environment, and teaching material should be used frequently in courses. In a study by Meadows (2004), it was stated that teachers should utilize information technologies and establish links between concepts and ideas. Brown, Collins and Duguid (1989) and Özkan (2001) stated that while instructing a certain topic to students, teachers should use specific activities related to daily life.

Note: This work was derived from the related part of the doctoral thesis entitled "Investigation of perceptions of the students and teachers on the implementation of seven principles of Chickering and Gamson in Science and Technology Courses" of Mustafa UĞRAŞ

\section{References}

Abdullah, S., \& Shariff, A. (2008). The effects of inquiry-based computer simulation with cooperative learning on scientific thinking and conceptual understanding of gas laws, Eurasia Journal of Mathematics, Science \& Techology Education, 4(4), 387-398.

Acar, B., \& Tarhan, L. (2008). Effects of cooperative learning on students' understanding of metallic bonding, Research in Science Education, 38(4), 401-420. https://doi.org/10.1007/s11165-007-9054-9

Akpınar, E. (2003). The science of invention of energy relations with the invention strategy: substance and energy unit for living things, (Unpublished master's thesis), Dokuz Eylül University, Institute of Educational Sciences, İzmir.

Aksoy, G. (2011). The effects of reading-writing-practice and co-learning techniques on students to understand the experiments in science and technology, (Doctor's thesis), Atatürk University, Erzurum.

Artut, P. D., \& Tarim, K. (2007). The Effectiveness of Jigsaw II on prospective elementary school teachers, Asia-Pacific Journal of Teacher Education, 35(2), 129-141. https://doi.org/10.1080/13598660701268551

Beaton, A. E., Martin, M. O., Mullis, I. V. S., Gonzalez, E. J., Smith, T. A., \& Kelly, D. L. (1996). Science achievement in the middle school yeras: IEA's Third International Mathematics and Science Study (TIMMS). Chestnut Hill, MA: Boston College, Center for the Study Testing, Evaluating, and Educational Policy.

Beck, M., \& Malley, J. (1998). Research into practice: a pedagogy of belonging. Reclaiming Children and Youth, 7(3), 133-137.

Bloom, B., (1979). Human Qualities and Learning at School (Çev. D. A. Özçelik), National Education Printing House, Ankara.

Brown, J. S., Collins, A., \& Duguid, P. (1989). Situated cognition and the culture of learning. Educational Researcher, 18, 32-42. https://doi.org/10.3102/0013189X018001032

Burden, P. R. (2003). Classroom Management, Creating A Successful Learning Community (Second Edition), Wiley, USA.

Cangelosi, J. S. (2004). Classroom management strategies, gaining and maintaining students' cooperation (5th. Edition), Wiley, USA

Chickering, A. W., \& Gamson, Z. F. (1987). Seven principles for good practice in undergraduate education. AAHE Bulletin, 39(7), 3-7.

Chickering, A., Gamson, Z., \& Barsi, L. (1989). Inventories of good practice in undergraduate education. Winona, MN: Seven Principles Resource Center, Winona State University

Çilenti, K. (1985). Science Education Technology, Kadığlu Matbaası, Ankara

Cox, A., Duncheon, N., \& McDavid, L. (2009). Peers and teachers as a source of relatedness perceptions, motivation, and affective responses in physical education. Research Quarterly for Exercise and Sport, 80, 765-773. https://doi.org/10.1080/02701367.2009.10599618

Creswell, J. W. (2003). Research design: Qualitative, quantitative, and mixed methods approaches(2nd ed.). Thousand Oaks, CA: Sage.

Çullu, F. (2003). The Effects of active learning on attribution, achievement, retention and students views, (Unpublished master's thesis), Dokuz Eylül University, Institute of Educational Sciences, İzmir.

Demirbaş, M., \& Yağbasan, R. (2005). The Analysis of Curriculum Development Studies Which are Applied for Effective Science Teaching at Primary Level in Turkey and Suggestions to Problems Encountered. Gazi University Kirsehir Education Faculty, 6(2), 53-67. https://doi.org/10.1080/02635140701847470 
Doymus, K. (2008). Teaching chemical bonding through jigsaw cooperative learning. Research in Science and Technological Education, 26(1), 47-57.

Gamson, Z. F. (1991). A brief history of the Seven Principles for Good Practice in Undergraduate Education. In A.W. Chickering \& Z.F. Gamson (Eds.), Applying the Seven Principles for Good Practice in Undergraduate Education, (pp. 5-12). https://doi.org/10.1002/tl.37219914703

Jennings, P. A., \& Greenberg, M. T. (2009). The prosocial classroom: Teacher social and emotional competence in relation to student and classroom outcomes. Review of Educational Research, 79, 491-525. https://doi.org/10.3102/0034654308325693

Johnson, J. K., \& Pontius, A. (1989). Homework: A survey of teacher beliefs and practices. Research in Education, 41, 71-78. https://doi.org/10.1177/003452378904100108

Jones, V. F., \& Jones, L. S. (1998). Comprehensive classroom management, creating communities of support and solving problems (Fifth edicition), Allyn ve Bacon, USA.

Lai, C. Y., \& Wu, C. C. (2006). Using handhelds in a jigsaw cooperative learning environment. Journal of Computer Assisted Learning, 22, 284-297. https://doi.org/10.1111/j.1365-2729.2006.00176.x

Meadows, J. (2004). Science and ICT in the Primary School: a Creative Approach to Big Ideas. London: David Fulton

MEB., (2005). Elementary Science and Technology Course (4th and 5th Grades) Curriculum, Ankara.

Mertoğlu, H. (2002). The effect of active learning methods in learning the nutrition concept of primary school eighth graders, (Unpublished master's thesis), Marmara University, Social Science Institute, İstanbul.

Muhlenbruk, L., Cooper, H., Nye, B., \& Lindsay, J. J. (2000). Homework and achievement: Explaining the different strengths of relation at the elementary and secondary school levels. Social Pyschology of Education, 3, 295-317. https://doi.org/10.1023/A:1009680513901

Özkan, B. (2001). The effectiveness of original activity and material use in constructivist learning environments, (Doctor's thesis), Hacatepe University, Social Science Institute, Ankara

Parvin, F. N. (1984). Integration of Communication Skills with Active Learning Techniques in Science. Dissertation Abstract International, 3(45).

Pascarella, E., Wolniak, G., Cruce, T., \& Blaich, C. (2004). Do liberal arts colleges really foster good practices in undergraduate education? Journal of College Student Development, 45, 57-74. https://doi.org/10.1353/csd.2004.0013

Peker, R. (1992). The Impact of University Students of Feedback on the Success of the Measurement and Evaluation Course, Uludağ University Journal of Education, 1(7).

Philip, M. (2011). A Comparison of Centralized and Decentralized Developmental Education Courses in Four Public Appalachian Community Colleges and Students' Perceptions Regarding the Seven Principles for Good Practice. Doctor of Education, College of Human Resources and Education at West Virginia University.

Postlethwaite, T. N., \& Wiley, D. E. (Eds). (1992). Science Achievement In Twenty-Three Countries The IEA Study Of Science II., Perganom Press Oxford.

Rosenthal, J. S. (1995). Active Learning Strategies in Advanced Mathematics Classes. Studies in Higher Education, 20(2), 223-229. https://doi.org/10.1080/03075079512331381723

Şahinel, M. G. (2003). Effective Learning, Pegem-A Yayınc1lık, Ankara.

Sarıkaya, T., \& Khorshid, L. (2009). The Investigation of The Factors that Affect University Students' Profession Choice: University Students' Profession Choice. Journal of Turkish Educational Sciences, 7(2), 393-423.

Senemoğlu, N. (1987). Cognitive input behaviors and feedback effect of feedback correction, (Unpublished master's thesis), H.Ü., Ankara.

Seyhan, G., \& Gür, H. (2002). Student Opinions on Active Learning Approach in Elementary 7th Grade Mathematics Teaching (16-18 September 2002, ODTÜ Culture and Convention Center). Ankara.

Sezgin, M. D. (2003). An Investigation of eight grade students achivement at probability unit instructed with active learning method, (Unpublished master's thesis), Uludag University, Social Sciences Institute, Bursa.

Souvignier, E., \& Kronenberger, J. (2007). Cooperative learning in third graders' Jigsaw groups for mathematics and science with and without questioning training, British Journal of Educational Psychology, 77, 755-771. https://doi.org/10.1348/000709906X173297 
Uysal, Ö. F. (1996). Effect of effective student participation on learning outcomes in the learning process, (Unpublished master's thesis), Dokuz Eylül University, Social Sciences Institute, İzmir.

Yanıkkerem, E., Altınparmak, S., \& Karadeniz, G. (2004). Young People's Factors and Self-esteem Affecting Career Choice, Nursing Forum Journal, 7(2), 61- 62.

Yunt, P. O. (1978). Effect of feedback and correction factors on school learning, (Unpublished doctor's thesis), H.Ü, Ankara.

\section{Copyrights}

Copyright for this article is retained by the author(s), with first publication rights granted to the journal.

This is an open-access article distributed under the terms and conditions of the Creative Commons Attribution license which permits unrestricted use, distribution, and reproduction in any medium, provided the original work is properly cited. 